\title{
HUBUNGANKARAKTER KEPEMIMPINAN DENGAN KINERJA \\ PENGUSAHA KECIL MAKANAN OLAHAN
}

\author{
Luh Dina Ekasari \\ Fakultas Ekonomi, Universitas Tribhuwana Tunggadewi Malang \\ Email: luhdinaekasari@gmail.com
}

\begin{abstract}
ABSTRAK
Cara seseorang memimpin tentu berbeda dengan orang lain. Cara seseorang mempengaruhi orang lain, bawahan atau kelompok, kemampuan mengarahkan tingkahlaku bawahan atau kelompok itulah yang disebut dengan karakteristik seorang pimpinan. Pimpinan harus memiliki kemampuan atau keahlian khusus dalam bidang yang diinginkan oleh kelompoknya untuk mencapai tujuan organisasi atau kelompok. Tujuannya untuk mengetahui adanya pengaruh gaya yang terdiri atas kepemimpinan Kharismatik, gaya kepemimpinan Demokratis, gaya kepemimpinan Otoriter, dan gaya kepemimpinan Moralis terhadap kinerja pengusaha kecil makanan olahan di Kelurahan Tlogomas, Kecamatan Lowokwaru, Kabupaten Malang.

Dalam penelitian ini peneliti menggunakan jenis penelitian kuantitatif, Lokasi penelitian dilakukan di Kelurahan Tlogomas, Kecamatan Lowokwaru Kota Malang. Berdasarkan objek penelitian yang penulis ambil jumlah sampel yang digunakan adalah 42 pengusaha. Dengan metode Wawancara, observasi dan kuesioner dan dilakukan uji validitas dan reliabilitas untuk analisis data menggunakan analisis linear berganda (uji simultan dan uji parsial).

Bahwa penelitian ini menyimpulkan gaya kepemimpinan kharismatik, kepemimpinan otoriter dan gaya kepemimpinan demokratis tidak berpengaruh terhadap kinerja pengusaha kecil makanan olahan. kepemimpinan moralis memiliki pengaruh yang signifikan terhadap kinerja pengusaha kecil makanan olahan.

\section{Kata Kunci: Gaya Kepemimpinan, Kinerja Pengusaha, Makanan Olahan}

\section{PENDAHULUAN}

Kepemimpinan merupakan suatu studi yang seharusnya mampu dipahami oleh seorang pemimpin dalam menggerakkan roda organisasinya. Dimulai dari tahapan pengertian muncullah konsep

kepemimpinan yang berisikan fungsifungsi dan berbagai macam gaya serta tipe kepemimpinan yang mampu dipilih dan diaplikasikan oleh seorang pemimpin. Akan tetapi perlu disadari oleh seorang pemimpin dan
\end{abstract}


orang yang ingin menjadi seorang pemimpin bahwa pada hakekatnya menjadi top leadher tidak cukup memahami hal tersebut diatas.

Kepemimpinan merupakan hal yang sangat krusial sekali untuk diimplementasikan diberbagai intansi baik dipemerintahan maupun di perusahaan skala kecil maupun skala besar termasuk dibidang usaha kecil karena selama ini banyak pengusaha kecil mengabaikan gaya kepemimpinan sehingga usaha yang mereka jalankan tidak membuahkan hasil yang maksimal dan kepemimpinan merupakan topik yang menarik untuk dikaji dan banyak aspek-aspek penting yang dijadikan pertimbangan-pertimbangan bagi seorang pemimpin khususnya dalam mengambil suatu keputusan. Oleh karena itu, sampai sekarang terus dipelajari, dipraktikan, dan diteliti.

Robbins (2006) menyatakan kepemimpinan adalah kemampuan untuk mempengaruhi kelompok menuju pencapaian sasaran. Kepemimpinan yang efektif adalah kemampuan/kecerdasan mendorong sejumlah orang agar bekerjasama dalam melaksanakan kegiatan-kegiatan yang terarah pada tujuan bersama. Kartono (2005) mengatakan kepemimpinan adalah kemampuan untuk memberikan pengaruh konstruktif kepada orang lain untuk melakukan suatu usaha kooperatif mencapai tujuan yang sudah direncanakan.

Dari beberapa definisi diatas dapat disimpulkan bahwa kepemimpinan merupakan kemampuan mempengaruhi orang lain, bawahan atau kelompok, kemampuan mengarahkan tingkahlaku bawahan atau kelompok, memiliki kemampuan atau keahlian khusus dalam bidang yang diinginkan oleh kelompoknya, untuk mencapai tujuan organisasi atau kelompok, ada empat gaya kepemimpinan berdasarkan kepribadian yaitu : Gaya Kepemimpinan Karismatik, Gaya Kepemimpinan Diplomatis, Gaya Kepemimpinan Otoriter, Gaya Kepemimpinan Moralis. Pengertian kinerja lainnya dikemukakan oleh Payaman Simanjuntak (2005) yang mengemukakan kinerja adalah tingkat pencapaian hasil atas pelaksanaan tugas tertentu. Kinerja perusahaan adalah tingkat pencapaian hasil dalam rangka mewujudkan tujuan perusahaan. Manajemen kinerja adalah keseluruhan kegiatan yang dilakukan untuk meningkatkan kinerja perusahaan atau organisasi, termasuk kinerja masingmasing individu dan kelompok kerja di 
perusahaan tersebut. Dessler (2009) berpendapat: Kinerja (prestasi kerja) karyawan adalah prestasi aktual karyawan dibandingkan dengan prestasi yang diharapkan dari karyawan. Prestasi kerja yang diharapkan adalah prestasi standar yang disusun sebagai acuan sehingga dapat melihat kinerja karyawan sesuai dengan posisinya dibandingkan dengan standar yang dibuat. Selain itu dapat juga dilihat kinerja dari karyawan tersebut terhadap karyawan lainnya. Berdasarkan beberapa pendapat tentang kinerja dan prestasi kerja dapat disimpulkan bahwa pengertian kinerja maupun prestasi kerja mengandung substansi pencapaian hasil kerja oleh seseorang. Dengan demikian bahwa kinerja maupun prestasi kerja merupakan cerminan hasil yang dicapai oleh seseorang atau sekelompok orang. Kinerja perorangan (individual performance) dengan kinerja lembaga (institutional performance) atau kinerja perusahaan (corporate performance) terdapat hubungan yang erat. Dengan perkataan lain bila kinerja karyawan (individual performance) baik maka kemungkinan besar kinerja perusahaan (corporate performance) juga baik.

\section{METODOLOGI}

Penelitian ini membahas tentang Pengaruh Gaya Kepemimpinan terhadap Kinerja Pengusaha Kecil Makanan Olahan, sesuai dengan permasalahan dalam penelitian ini dimana metode penelitian yang digunakan adalah metode kuantitatif. Lokasi dalam penelitian ini adalah pengusaha kecil makanan olahan di Kelurahan Tlogomas, Kecamatan Lowokwaru Kota Malang. Dalam penelitian jumlah populasi adalah seluruh Pengusaha Kecil Makanan Olahan di Kelurahan Tlogomas, Kecamatan Lowokwaru Kota Malang.

Sampel adalah bagian dari jumlah dan karakteristik yang dimiliki oleh populasi tersebut. Teknik pengambilan sampel dalam penelitian ini menggunakan metode cluster random sampling. Berdasarkan objek penelitian yang penulis ambil Pengusaha Kecil Makanan Olahan di Kelurahan Tlogomas dengan jumlah 42 pengusaha. Kriteria untuk penilaian responden dengan menggunakan skala likert dengan skala 1 sampai 5 dengan kriteria adalah sebagai berikut:

Sangat setuju (SS) Diberi nilai $=5$, Setuju (S) diberi nilai $=4$, Cukup setuju (CS) diberi nilai $=3$, Tidak setuju (TS) diberi nilai $=2$, Sangat tidak setuju (STS) diberi 
nilai $=1$. Variabel adalah suatu hal yang berbentuk apa saja yang ditetapkan oleh peneliti untuk dipelajari sehingga diperoleh informasi tentang hal tersebut, kemudian ditarik kesimpulannya. Mengacu pada permasalahan yang diajukan, maka variabel-variabel yang akan diteliti dikelompokkan menjadi dua variabel yaitu:

1. Variabel bebas (X)

Yang merupakan variabel bebas dalam penelitian ini adalah Gaya kepemimpinan sebagai berikut:

a) Gaya kepemimpinan karismatik $\left(\mathrm{X}_{1}\right)$

1. Memiliki visi yang amat kuat atau kesadaran tujuan yang jelas $\left(\mathrm{X}_{1.1}\right)$

2. Mengkomunikasikan visi itu secara efektif $\left(\mathrm{X}_{1.2}\right)$

3. Mendemontrasikan konsistensi dan fokus $\left(\mathrm{X}_{1.3}\right)$

4. Mengetahui kekuatan-kekuatan sendiri dan memanfaatkannya $\left(\mathrm{X}_{1.4}\right)$

b) Gaya kepemimpinan Demokratis $\left(\mathrm{X}_{2}\right)$

1. Mengikut sertakan karyawan dalam pengambilan keputusan $\left(\mathrm{X}_{2.1}\right)$

2. Lebih memperhatikan bawahan untuk mencapai tujuan organisasi $\left(\mathrm{X}_{2.2}\right)$
3. Pimpinan bersedia melimpahkan sebagian wewenang kepada bawahan $\left(\mathrm{X}_{2.3}\right)$

4. Komunikasi berlangsung secara timbal balik, baik yang terjadi antara pimpinan dan bawahan maupun sesama bawahan $\left(\mathrm{X}_{2.4}\right)$

c) Gaya kepemimpinan otoriter $\left(\mathrm{X}_{3}\right)$

1. Adanya pencapaian prestasi $\left(\mathrm{X}_{3.1}\right)$

2. memiliki sifat yang sopan terhadap semua orang $\left(\mathrm{X}_{3.2}\right)$

3. Tidak ada alasan, yang ada adalah $\operatorname{hasil}\left(\mathrm{X}_{3.3}\right)$

4. Sifat pemimpin ini dingin dan sedikit kejam $\left(\mathrm{X}_{3.4}\right)$

d) Gaya kepemimpinan moralis $\left(\mathrm{X}_{4}\right)$

1. Hubungan atasan dan bawahan bisa terjalin dengan baik $\left(\mathrm{X}_{4.1}\right)$

2. Mampu mempengaruhi orang lain agar mau bekerja sama $\left(\mathrm{X}_{4.2}\right)$

3. Gaya kepemimpinannya hangat dan sopan $\left(\mathrm{X}_{4.3}\right)$

4. Memiliki empati yang tinggi terhadap permasalahan para bawahannya $\left(\mathrm{X}_{4.4}\right)$

2. Variabel terikat (Y)

Yang merupakan variabel terikat dalam penelitian ini adalah kinerja pengusaha kecil dengan indikator kinerja pengusaha kecil adalah sebagai berikut : 
a) Pengetahuan $\left(\mathrm{Y}_{1.1}\right)$

b) Pengalaman $\left(\mathrm{Y}_{1.2}\right)$

c) Kepribadian $\left(\mathrm{Y}_{1.3}\right)$

Sumbr data dalam penelitian ini adalah sumber data primer dan data sekunder. 1) Data primer yaitu data yang didapat secara langsung dari jawaban responden, melalui kuesioner yang telah dirancang sesuai dengan variabel, indicator serta item yang telah ditetapkan. 2) Data sekunder yaitu data yang diperoleh secara tidak langsung atau dicatat oleh pihak lain dengan cara mengumpulkan informasi referensi, jurnal dan laporan yang relevan dengan penelitian yang sedang dilakukan.

Teknik pengumpulan data yang digunakan adalah Wawancara, Observasi dan Kuesioner atau angket. Selanjutnya dilakukan pengujian data, yaitu uji validitas dan uji realibilitas. 1) Validitas adalah suatu ukuran yang menunjukkan tingkat-tingkat kevali dan atau kesahihan instrumen. Sebuah instrumen dikatakan valid apabila dapat mengungkap data dari variabel yang diteliti secara tepat. Instrumen dapat dikatakan valid apabila propabilitas (p) pada masing-masing butir pertanyaan kurang dari 0,05. Rumus yang digunakan untuk mencari nilai korelasi adalah korelasi pearson product moment yang dirumuskan sebagai berikut:

$$
\mathbf{r}_{\mathrm{Xy}}=\frac{N \sum X Y-\left(\sum x\right)\left(\sum Y\right)}{\sqrt{\left(N \sum X^{2}-\left(\sum X\right)^{2}\left(N \sum Y^{2}\left(\sum Y\right)^{2}\right.\right.}}
$$

Dimana:

$$
\begin{array}{ll}
\mathrm{r}_{\mathrm{xy}} & =\text { Koefisien korelasi } \\
\mathrm{N} & =\text { Banyaknya sampel } \\
\mathrm{X} & =\text { Skor item } \mathrm{X} \\
\mathrm{Y} & =\text { Skor item } \mathrm{Y}
\end{array}
$$

2) Reliabilitas merupakan istilah yang dipergunakan untuk menunjukkan sejauh mana suatu hasil pengukuran relatif konsisten apabila pengukuran dilakukan berulang-ulang. Instrumen yang baik tidak akan bersifat tendensius mengarahkan responden untuk memilih jawaban-jawaban tertentu. Dasar pengambilan keputusan apakah suatu item atau variabel reliabel atau tidak adalah $\alpha$ lebih dari atau sama dengan 0,6. Rumus yang digunakan untuk mencari nilai reliabilitas instrument adalah Alpha yang dirumuskan sebagai berikut:

$$
\mathrm{r}_{11}=\left[\frac{k}{(k-1)}\right]\left[\frac{1-\sum \sigma_{3}^{2}}{\sigma_{1}^{2}}\right]
$$

Dimana:

$$
\begin{array}{ll}
\mathrm{r}_{11} & =\text { Reliabilitas Instrumen } \\
\mathrm{k} & =\text { Banyaknya butir pertanyaan } \\
\sigma_{3}{ }^{2} & =\text { Jumlah varian butir } \\
\sigma_{1}{ }^{2} & =\text { Varian total }
\end{array}
$$

\section{Teknik Analisis Data}

Penelitian ini menggunakan analisis regresi linear berganda, ini 
merupakan model statistik yang digunakan untuk mengukur seberapa besar pengaruh beberapa variabel bebas terhadap variabel terikat. Adapun hubungan ini ditunjukkan dengan persamaan yang menggunakan rumus sebagai berikut:

$$
Y=a+b_{1} x_{1}+b_{2} x_{2}+b_{3} x_{3}+b_{4} x_{4}
$$

dimana:

$\mathrm{Y}=$ Kinerja Pengusaha olahan makanan kecil

$\mathrm{x}_{1}=$ Total skor faktor gaya kepemimpinan karismatik

$\mathrm{x}_{2}=$ Total skor faktorgaya kepemimpinan demokratis

$\mathrm{x}_{3}=$ Total skor faktor gaya kepemimpinan otoriter

$\mathrm{x}_{4}=$ Total skor faktor gaya kepemimpinan moralis

$\mathrm{a}=$ Intercept (konstant)

$\mathrm{b}=\quad$ Koefisien arah regresi

\section{HASIL DAN PEMBAHASAN}

Objek yang diteliti adalah seluruh pengusaha yang ada di Kelurahan Tlogomas, Kecamatan Lowokwaru berjumlah 42 responden, terdiri dari 22 responden laki-laki dan 20 responden berjenis kelamin perempuan. Berikut akan digolongkan umur responden:

Tabel 1. Rekapitulasi Jumlah Responden Berdasarkan Usia

\begin{tabular}{|c|c|c|c|}
\hline No & Usia & Responden & \% \\
\hline 1 & $25-35$ & 15 & 35,71 \\
\hline 2 & $36-45$ & 19 & 45,24 \\
\hline 3 & $46-45$ & 8 & 19,05 \\
\hline \multicolumn{2}{|c|}{ Total } & 42 & 100,00 \\
\hline
\end{tabular}

Sumber: Data Primer Diolah. 2013

Dapat disimpulkan bahwa dari jumlah responden 42 orang, yang paling banyak menjawab kuisioner berdasarkan usia pada tabel 4.1 diatas adalah berjumlah 19 orang $45,24 \%$ (36-45 tahun).

Berdasarkan data tingkat pendidikan, maka dapat dijelaskan bahwa jumlah responden berjumlah 42 orang dan mempunyai tingkat pendidikan paling dominan yaitu tingkat SD berjumlah 21 orang $(51,22 \%)$. Dapat disimpulkan bahwa pengusaha kecil makanan olahan di Kecamatan Lowokwaru sebagian besar berpendidikan tamatan SD.

Lamanya usaha yang dijalankan oleh pengusaha kecil makanan olahan yang ada di Kelurahan Tlogomas, Kecamatan Lowokwaru, Kabupaten Malang yang berkisar antara 2 bulan sampai 36 tahun lamanya usaha kecil makanan olahan yang dijalankan sampai tahun 2013 saat ini. 
HASIL ANALISIS

\section{Deskripsi Variabel Gaya}

Kepemimpinan Kharismatik (X1)

Untuk mengetahui jawaban responden secara keseluruhan berdasarkan keterlibatan Gaya Kepemimpinan Karismatik terhadap kinerja pengusaha terlihat pada tabel berikut:

Tabel 2. Karakteristik Berdasarkan

Variabel Gaya Kepemimpinan

Kharismatik (X1)

\begin{tabular}{|c|l|c|c|}
\hline No & $\begin{array}{c}\text { Kategori } \\
\text { Jawaban }\end{array}$ & Frekuensi & $\begin{array}{c}\text { Presentase } \\
(\%)\end{array}$ \\
\hline 1 & Sangat setuju & 8 & 19 \\
\hline 2 & Setuju & 25 & 58 \\
\hline 3 & Cukup setuju & 10 & 23 \\
\hline 4 & Tidak setuju & 0 & 0 \\
\hline 5 & $\begin{array}{l}\text { Sangat tidak } \\
\text { setuju }\end{array}$ & 0 & 0 \\
\hline \multicolumn{2}{|l|}{ Total } & 42 & $100 \%$ \\
\hline
\end{tabular}

Dari tabel dapat disimpulkan bahwa dari keseluruhan jawaban responden yang berjumlah 42 orang yaitu yang menyatakan sangat setuju berjumlah 8 orang (19\%), yang menyatakan setuju berjumlah 25 orang (58\%), dan responden yang menyatakan cukup setuju berjumlah 10 orang $(23 \%)$.

Sehingga dapat dimaknai bahwa dari jawaban responden mengenai gaya kepemimpinan kharismatik terhadap kinerja pengusaha yaitu pentingnya setiap pengusaha mempunyai gaya kepemimpinan kharismatik untuk meningkatkan kinerja pengusaha atas usaha yang dijalankan, sedangkan sebagian kecil dari responden menyatakan tidak setuju.

\section{Deskripsi Variabel Gaya}

\section{Kepemimpinan Demokratis (X2)}

Berikut akan dijelaskan tentang jawaban responden secara keseluruhan berdasarkan variabel gaya kepemimpinan demokratis yang mempengaruhi kinerja pengusaha yang ada di Kelurahan Tlogomas, kecamatan lowokwaru dapat dilihat pada tabel di bawah ini:

Tabel 3.Karakteristik Berdasarkan Variabel Gaya Kepemimpinan

Demokratis (X2)

\begin{tabular}{|c|l|c|c|}
\hline No & Kategori & Frekuensi & $\begin{array}{c}\text { Presentase } \\
(\%)\end{array}$ \\
\hline 1 & $\begin{array}{l}\text { Sangat } \\
\text { setuju }\end{array}$ & 6 & 14 \\
\hline 2 & Setuju & 26 & 63 \\
\hline 3 & $\begin{array}{l}\text { Cukup } \\
\text { setuju }\end{array}$ & 9 & 22 \\
\hline 4 & $\begin{array}{l}\text { Tidak } \\
\text { setuju }\end{array}$ & 1 & 2 \\
\hline 5 & $\begin{array}{l}\text { Sangat } \\
\text { tidak } \\
\text { setuju }\end{array}$ & 0 & 0 \\
\hline \multicolumn{2}{|c|}{ Total } & 42 & $100 \%$ \\
\hline
\end{tabular}

Dari tabel di atas, dapat dijelaskan bahwa yang menjawab sangat setuju berjumlah 6 orang (14\%), sedangkan yang setuju berjumlah 26 orang (23\%), dan yang menjawab cukup setuju 9 orang (22\%). Dapat disimpulkan bahwa dari variabel gaya kepemimpinan demokratis berdasarlan seluruh jawaban responden 
yang menyatakan setuju adalah sangat dibutuhkan gaya kepemimpinan demokratis, sedangkan sebagian kecil yang menyatakan tidak setuju.

Deskripsi

Variabel

Gaya

\section{Kepemimpinan Otoriter (X3)}

Berikut akan dijelaskan gaya kepemimpinan otoriter terhadap kinerja pengusaha berdasarkan hasil seluruh jawaban responden dapat dilihat pada tabel di bawah ini:

Tabel 5.Karakteristik Jawaban

Responden Berdasarkan

Variabel Gaya Kepemimpinan

Otoriter (X3)

\begin{tabular}{|c|l|c|c|}
\hline No & Kategori & Frekuensi & $\begin{array}{c}\text { Presentase } \\
(\%)\end{array}$ \\
\hline 1 & $\begin{array}{l}\text { Sangat } \\
\text { setuju }\end{array}$ & 4 & 8 \\
\hline 2 & Setuju & 8 & 19 \\
\hline 3 & $\begin{array}{l}\text { Cukup } \\
\text { setuju }\end{array}$ & 17 & 40 \\
\hline 4 & Tidak setuju & 14 & 33 \\
\hline 5 & $\begin{array}{l}\text { Sangat tidak } \\
\text { setuju }\end{array}$ & 0 & 0 \\
\hline \multicolumn{2}{|l|}{ Total } & 42 & $100 \%$ \\
\hline
\end{tabular}

Berdasarkan tabel dapat dijelaskan bahwa dari variabel gaya kepemimpinan otoriter, keseluruhan jawaban responden yang menjawab sangat setuju hanya berjumlah 4 orang ( $8 \%)$, sedangkan yang menjawab setuju 8 orang (19\%), dan yang menjawab cukup setuju dan tidak setuju berjumlah 17 - 14 orang (40\% - 33 $\%)$.
Dapat disimpulkan bahwa dari karakteristik seluruh jawaban responden yang berjumlah 42 orang yang menjawab lebih besar menyatakan tidak setuju dari pada menyatakan setuju, artinya gaya kepemimpinan otoriter tidak terlalu disukai responden untuk meningkatkan kinerja dikalangan pengusaha olahan makanan.

\section{Deskripsi Variabel Gaya}

\section{Kepemimpinan Moralis (X4)}

Berikut akan ditampilkan variabel gaya kepemimpinan moralis terhadap kinerja karyawan berdasarkan seluruh jawaban responden untuk lebih jelasnya dapat dilihat pada tabel di bawah ini:

Tabel 6. Karakteristik Jawaban

Responden Berdasarkan

Variabel Gaya Kepemimpinan

Moralis (X4)

\begin{tabular}{|c|l|c|c|}
\hline No & Kategori & Frekuensi & $\begin{array}{c}\text { Presentase } \\
(\%)\end{array}$ \\
\hline 1 & $\begin{array}{l}\text { Sangat } \\
\text { setuju }\end{array}$ & 6 & 14 \\
\hline 2 & Setuju & 28 & 67 \\
\hline 3 & $\begin{array}{l}\text { Cukup } \\
\text { setuju }\end{array}$ & 8 & 18 \\
\hline 4 & $\begin{array}{l}\text { Tidak } \\
\text { setuju }\end{array}$ & 0 & 0 \\
\hline 5 & $\begin{array}{l}\text { Sangat } \\
\text { tidak } \\
\text { setuju }\end{array}$ & 0 & 0 \\
\hline \multicolumn{2}{|c|}{ Total } & 42 & $100 \%$ \\
\hline
\end{tabular}

Berdasarkan tabel 4.6 di atas dari

hasil karakteristik jawaban seluruh responden atas variabel gaya kepemimpinan moralis terhadap kinerja 
yang menjawab sangat setuju 6 orang (14\%), sedangkan menjawab setuju 28 orang $(67 \%)$ dan menjawab cukup setuju 8 orang (18).

Dapat ditarik kesimpulan dari seluruh jawaban responden atas variabel gaya kepemimpinan moralis terhadap kinerja lebih banyak diminati, karena lebih dari $67 \%$ orang menyatakan setuju dari pada menyatakan tidak setuju.

\section{Variabel Terikat (dependent Variable)}

\section{Yaitu Kinerja Pengusaha (Y)}

Untuk mengetahui seluruh karakteristik dari jawaban responden berdasarkan variabel kinerja pengusaha (Y) dapat dilihat pada tabel di bawah ini:

Tabel 7. Karakteristik Jawaban

Responden Berdasarkan

Variabel Terikat Yaitu Kinerja

Pengusaha (Y)

\begin{tabular}{|c|l|c|c|}
\hline No & Kategori & Frekuensi & $\begin{array}{c}\text { Presentase } \\
(\boldsymbol{\%})\end{array}$ \\
\hline 1 & $\begin{array}{l}\text { Sangat } \\
\text { setuju }\end{array}$ & 16 & 37 \\
\hline 2 & Setuju & 23 & 55 \\
\hline 3 & $\begin{array}{l}\text { Cukup } \\
\text { setuju }\end{array}$ & 3 & 8 \\
\hline 4 & $\begin{array}{l}\text { Tidak } \\
\text { setuju }\end{array}$ & 0 & 0 \\
\hline 5 & $\begin{array}{l}\text { Sangat } \\
\text { tidak } \\
\text { setuju }\end{array}$ & 0 & 0 \\
\hline \multicolumn{2}{|c|}{ Total } & $\mathbf{4 2}$ & $\mathbf{1 0 0 \%}$ \\
\hline
\end{tabular}

Berdasarkan tabel 4.7 di atas dari karakteristik responden yang berjumlah 42 orang yang menjawab atas variabel kinerja pengusaha yang menyatakan sangat setuju berjumlah 16 orang (37\%), sedangkan yang menyatakan setuju 23 orang (55\%) dan yang menyatakan cukup setuju 3 orang $(8 \%)$.

Dapat ditarik kesimpulan, berdasarkan jawaban kuesioner yang diajukan kepada responden terhadap kinerja pengusaha makanan olahan di Kelurahan Tlogomas, Kecamatan Lowokwaru lebih baik sesuai dengan jawaban responden yang dijelaskan di atas.

\section{Analisis Pembahasan}

Uji Validitas menunjukkan bahwa pada tingkat signifikan 5\% sejumlah instrumen yang digunakan dalam penelitian Pengaruh Gaya Kepemimpinan Terhadap Kinerja Pengusaha Kecil Makanan Olahan di Kelurahan Tlogomas, Kecamatan Lowokwaru Diperoleh nilai koefisien korelasi lebih besar dari nilai r-tabel Produk Moment sebesar 0,294. Dengan demikian dapat dikatakan bahwa instrumen dalam penelitian ini adalah valid atau dapat mengukur variabel yang diteliti. 
Uji Realibilitas menunjukkan bahwa nilai koefisien realibilitas masingmasing variabel yang digunakan, dalam variabel Gaya Kepemimpinan (X) dan Kinerja Pengusaha (Y) lebih dari nilai rtabel sebesar 0.6 maka hasil jawaban responden dapat diandalkan dengan kata lain bahwa apabila dilakukan penelitian yang sama dalam waktu yang berbeda maka responden akan memberikan jawaban yang sama.

\section{Analisis Regresi Berganda}

Dalam penelitian ini, uji hipotesis menggunakan SPSS 16.0 For windows dengan menguji regresi berganda yang merupakan analisis untuk mengetahui besarnya pengaruh antara 2 (dua) atau lebih variabel bebas (Indevendent Variable) terhadap variabel terikat (Dependent Variable) dengan tingkat kepercayaan $95 \%$ atau tingkat signifikan $5 \%(a=0,05)$. Persamaan regresi linier berganda sebagai berikut:

$$
\begin{aligned}
& Y=9.067+0.130 X_{1}+-0.404 X_{2}+ \\
& 0.057 X_{3}+0.468 X_{4}
\end{aligned}
$$

Dari persamaan regresi linier sebagai berikut:

1. Konstanta sebesar 9.067 menunjukkan besarnya pengaruh gaya kepemimpinan jika variabel tingkat gaya kepemimpinan kharismatik, demokratis, otoriter dan gaya kepemimpinan moralis

2. Koefisien variabel gaya kepemimpinan kharismatik $\left(\mathrm{X}_{1}\right)$ sebesar 0,130 menunjukkan tidak berpengaruh atas gaya kepemimpinan kharismatik terhadap kinerja pengusaha artinya gaya kepemimpinan kharismatik tidak meningkatkan atau menurunkan kinerja pengusaha.

3. Koefisien variabel gaya kepemimpinan demokratis $\left(\mathrm{X}_{2}\right)$ sebesar -0.404 menunjukkan gaya kepemimpinan demokratis tidak berpengaruh terhadap kinerja pengusaha kecil.

4. Koefisien variabel gaya kepemimpinan otoriter $\left(\mathrm{X}_{3}\right)$ sebesar 0.057 menunjukkan gaya kepemimpinan otoriter tidak berpengaruh terhadap kinerja pengusaha.

5. Koefisien variabel gaya kepemimpinan moralis $\left(\mathrm{X}_{4}\right)$ sebesar 0.468 menunjukkan berpengaruh terhadap gaya kepemimpinan moralis terhadap kinerja pengusaha artinya gaya kepemimpinan moralis meningkatkan kinerja pengusaha.

Adapun nilai koefisien determinasi sebagaimana pada tabel hasil analisis 
regresi dan model summary diperoleh nilai $R$ square $\left(R^{2}\right)=0,360$ yang berarti bahwa besarnya pengaruh variabel gaya kepemimpinan (kharismatik, demokratis, otoriter dan moralis) terhadap kinerja pengusaha di Kelurahan Tlogomas, Kecamatan Lowokwaru adalah sebesar $36,0 \%$, sedangkan sisanya $(64,0 \%)$ dipengaruhi oleh variabel lain yang dalam penelitian ini tidak diteliti/dikaji.

\section{Pengujian Hipotesis}

Dari Uji $F$ diperoleh nilai $F_{\text {hitung }}$ sebesar 5,196>4,807 dengan nilai signifikasi (Sig.) hasil penelitian sebesar $0,002<0,05$ maka berarti $\mathrm{H}_{0}$ ditolak dan $\mathrm{H}_{1}$ diterima sehingga dapat disimpulkan bahwa variabel terikat kinerja pengusaha dipengaruhi secara simultan oleh variabel bebas. Sehingga hipotesis yang menyatakan variabel pengaruh gaya kepemimpinan kharismatik, demokratis, otoriter dan moralis berpengaruh signifikan terhadap kinerja pengusaha. Sedangkan pengujian parsial (Uji t) didapat hasil sebagai berikut:

1. Uji $t$ antara variabel gaya kepemimpinan kharismatik (X1) dengan kinerja pengusaha (Y) menunjukkan bahwa gaya kepemimpinan kharismatik tidak berpengaruh yang signifikan terhadap kinerja pengusaha, hal ini dapat diketahui dengan membandingkan nilai $\mathrm{t}$ hitung sebesar $0,923<1,687$ dengan nilai signifikasi penelitian dengan signifikasi yang ditentukan $(a=0,05)$. Signifikasi penelitian sebesar $0,003<0,05$ maka $\mathrm{H}_{0}$ diterima dan $\mathrm{H}_{1}$ ditolak sehingga hipotesis yang menyatakan gaya kepemimpinan kharismatik berpengaruh secara parsial terhadap kinerja pengusaha tidak dapat diterima.

2. Uji $\mathrm{t}$ antara gaya kepemimpinan demokratis (X2) dengan kinerja pengusaha (Y) menunjukkan bahwa gaya kepemimpinan demokratis tidak memiliki pengaruh signifikan terhadap kinerja pengusaha, hal ini dapat diketahui dengan membandingkan nilai $\mathrm{t}$ hitung sebesar 2-718 < 1,687 nilai signifikansi penelitian sebesar 0,010>0,05 maka $\mathrm{H}_{0}$ ditolak dah $\mathrm{H}_{1}$ diterima sehingga hipotesis yang menyatakan variabel gaya kepemimpinan demokrati berpengaruh secara parsial terhadap kinerja pengusaha tidak dapat diterima.

3. Uji t variabel gaya kepemimpinan otoriter (X3) dengan kinerja pengusaha (Y) menunjukan bahwa gaya kepemimpinan otoriter tidak pengaruh yang signifikan terhadap variabel kinerja pengusaha, hal ini dapat diketahui dengan membandingkan nilai $\mathrm{t}$ hitung sebesar $0,715<1,687$ nilai signifkasi penelitian 
dengan signifikasi yang ditentukan $(a=$ 0.05). signifikasi penelitian sebesar 0,479 > 0,05 maka $\mathrm{H}_{0}$ diterima dan $\mathrm{H}_{1}$ ditolak sehingga hipotesis yang menyatakan variabel gaya kepemimpinan otoriter berpengaruh terhadap kinerja pengusaha tidak dapat diterima.

4. Uji t variabel gaya kepemimpinan moralis (X4) dengan variabel kinerja pengusaha (Y) menunjukkan bahwa gaya kepemimpinan moralis pengaruh signifikan terhadap kinerja pengusaha hal ini dapat diketahui dengan membandingkan nilai $\mathrm{t}$ hitung sebesar $3,610>1,687$ nilai signifikasi penelitian dengan signifikasi yang ditentukan ( $a=$ $0,05)$. signifikasi penelitian sebesar 0,001 $<0,05$ maka $\mathrm{H}_{0}$ diterima dan $\mathrm{H}_{1}$ ditolak sehingga hipotesis yang menyatakan variabel gaya kepemimpinan moralis berpengaruh terhadap kinerja pengusaha dapat diterima.

\section{Pengaruh Variabel Gaya}

Kepemimpinan Kharismatik Terhadap Kinerja Pengusaha

Dalam penelitian ini variabel pengaruh gaya kepemimpinan kharismatik merupakan variabel bebas (X1) yang tidak memiliki pengaruh yang signifikan terhadap kinerja pengusaha sebagai variabel terikat (Y). Dan terdapat hubungan yang tidak searah yang ditunjukkan nilai koefisien regresi (X1) sebesar 0,130. Hal ini dipengaruhi oleh berbagai faktor salah satunya adalah kurang mampu dalam meningkatkan kualitas ataupun skill diri seorang pemimpin adalah sebagai kelangsungan usaha yang dijalankan.

\section{Pengaruh Variabel Gaya}

Kepemimpinan Demokratis Terhadap Kinerja Pengusaha

Dalam hasil penelitian atas variabel gaya kepemimpinan demokratis sebagai variabel bebas (X2) ini tidak memiliki pengaruh yang signifikan terhadap kinerja pengusaha sebagai variabel terikat (Y) dan tidak terdapat hubungan yang searah terhadap gaya kepemimpinan demokratis terhadap kinerja karyawan sesuai dengan hasil hitungan koefisien regresi sebesar $-0,404$.

\section{Pengaruh Variabel Gaya Kepemimpinan Otoriter Terhadap Kinerja Pengusaha}

Hasil analisis membuktikan bahwa variabel gaya kepemimpinan otoriter (X3) tidak memiliki pengaruh signifikan terhadap kinerja pengusaha (Y) dan terdapat hubungan yang tidak searah yang ditunjukkan nilai koefisien regresi 
(X3) yang bertanda positif sebesar 0,057.

Hal ini dipengaruhi oleh berbagai faktor salah satunya adalah kurangmampunya dalam pengembangan diri dan meningkatkan skill terhadap kepemimpinan.

\section{Pengaruh Variabel Gaya Kepemimpinan Moralis Terhadap Kinerja Pengusaha}

Hasil analisis membuktikan bahwa variabel gaya kepemimpinan moralis (X4) memiliki pengaruh yang signifikan terhadap variabel kinerja pengusaha $(\mathrm{Y})$ dan terdapat hubungan yang searah dapat ditunjukkan nilai koefisien regresi (X4) yang bertanda positif sebesar 0,468 .

\section{KESIMPULAN}

Berdasarkan hasil perhitungan penelitian, dapat disimpulkan yaitu:

1. Bahwa gaya kepemimpinan kharismatik tidak berpengaruh terhadap kinerja pengusaha kecil makanan olahan hal ini dapat dilihat dari data hasil rekapitulasi variabel X1 sebesar 0,130 yang menunjukkan tidak searah. Dikarenakan dipengaruhi oleh berbagai faktor salah satunya adalah kurang mampu dalam meningkatkan kualitas ataupun skill diri seorang pemimpin sebagai kelangsungan usaha yang dijalankan.

2. Bahwa gaya kepemimpinan demokratis pada pengusah makanan olahan di Kecamatan Lowokwaru tidak memiliki pengaruh yang signifikan terhadap kinerja pengusaha kecil dan tidak mempunyai hubungan yang searah terhadap kinerja karyawan sesuai dengan hasil hitungan koefisien regresi sebesar 0,404 .

3. Bahwa gaya kepemimpinan otoriter terhadap kinerja pengusaha olahan di Kelurahan Tlogomas Kecamatan Lowokwaru tidak memiliki pengaruh signifikan dan terdapat hubungan yang tidak searah yang ditunjukkan nilai koefisien regresi (X3) sebesar 0,057. Hal ini dipengaruhi oleh berbagai faktor salah satunya adalah kurang mampu dalam pengembangan diri dan meningkatkan skill terhadap kepemimpinan.

4. Bahwa gaya kepemimpinan moralis terhadap kinerja pengusaha makanan olahan di Kecamatan Lowokwaru memiliki pengaruh yang signifikan dan terdapat hubungan yang searah dapat ditunjukkan nilai koefisien regresi (X4) sebesar 0,468. Hal ini menunjukkan hubungan yang positif terhadap pengaruh kinerja pengusaha makanan olahan di 
Kelurahan Tlogomas Kecamatan

Lowokwaru.

Dari variabel bebas $\mathrm{X}$ (gaya kepemimpinan kharismatik, demokratis, otoriter dan moralis) terhadap kinerja pengusaha makanan olahan di Kecamatan Lowokwaru, Kabupaten Malang. yang paling dominan berpengaruh atau mempunyai pengaruh signifikan terhadap kinerja pengusaha adalah terlihat dari variabel X4 yaitu gaya kepemimpinan moralis, sedangkan dari variabel lainnya tidak mempengaruhi atas variabel kinerja pengusaha, dimana dari variabel lainnya tidak memberikan peningkatan dan penurunan terhadap kinerja pengusaha yang ada di Kecamatan Lowokwaru Kabupaten Malang.

\section{KEPUSTAKAAN}

Robbins, S. P. 2006. Teori Organisasi: Struktur, Desain dan Aplikasi. Alih Bahasa: Yusuf Udaya. Jakarta: Arcan.

Kartono, Kartini. 2005. Kepemimpinan: Apakah Kepemimpinan Abnormal itu?. Jakarta: Raja Grafindo Persada.

Payaman J. Simanjuntak, 2005, Manajemen dan Evaluasi Kinerja, Jakarta: Lembaga Penerbit Fakultas Ekonomi UI.

Dessler, Gary (2009). Manajemen Sumber Daya Manusia. Jakarta: INDEKS 